\title{
The effect of planting, seeding and soil preparation on the regeneration success of Scots pine (Pinus sylvestris L.) on drained peatlands - 10-year results
}

\author{
Jyrki Hytönen $^{1 *}$, Hannu Hökkä ${ }^{2}$ and Markku Saarinen ${ }^{3}$
}

\begin{abstract}
Hytönen, J., Hökkä, H., Saarinen, M. 2020. The effect of planting, seeding and soil preparation on the regeneration success of Scots pine (Pinus sylvestris L.) on drained peatlands - 10year results. - Forestry Studies | Metsanduslikud Uurimused 72, 91-106, ISSN 1406-9954. Journal homepage: http://mi.emu.ee/forestry.studies
\end{abstract}

\begin{abstract}
We studied the effect of regeneration (planting/seeding) and soil preparation methods (no soil preparation/scalping/mounding) on the regeneration success of Scots pine (Pinus sylvestris L.) on three drained peatland Scots pine stands in northern Finland. After ten years, planting and sowing showed no differences in the total number of Scots pine seedlings (one seedling per sowing spot accepted) with the exception of the Sievi experiment. Without soil preparation the total number of Scots pine seedlings was 350-600 per ha. Scalping increased the number of Scots pine seedlings to 550-900 per ha, with the exception of seeding at Sievi. In mounded plots, with the exception of seeded plots at the Sievi site, the number of planted or seeded seedlings was 1,325-2,350 per ha. The number of crop seedlings in all the experiments and for all the soil preparation treatments reached the target of 2,000 seedlings per ha if naturally regenerated Scots pine, Norway spruce (Picea abies (L.) H. Karst.) or birch (Betula spp.) seedlings were accepted as such. Moose (Alces alces L.) damage in Scots pine crop seedlings ranged from $4 \%$ in Sievi to $65 \%$ in Simo. The proportion of planted or seeded Scots pines of the crop seedlings was $23 \%$ in unprepared plots, $30 \%$ in scalped plots and $75 \%$ in mounded plots. Mounding increased the share of Scots pine seedlings in the overall crop seedlings. Planted seedlings were taller than seeded seedlings. Planting in mounds gave the best overall results in terms of the number of crop seedlings and their height ten years after the treatment.
\end{abstract}

Key words: mounding, scalping, planting, seeding, peatland, regeneration.

Authors' addresses: ${ }^{1}$ Natural Resources Institute Finland, Natural Resources, Teknologiakatu 7, FI-67100 Kokkola, Finland, ${ }^{2}$ Natural Resources Institute Finland, Natural Resources, Paavo Havaksen tie 3, FI-90570 Oulu, Finland, ${ }^{3}$ Natural Resources Institute Finland, Natural Resources, Kampusareena, Korkeakoulunkatu 7, FI-33720 Tampere, Finland, * e-mail: jyrki.hytonen@luke.fi

\section{Introduction}

Most of the drainage of peatlands for forestry, totaling 4.7 million ha in Finland (Hökkä et al., 2002; Päivänen \& Hånell, 2012), was done in the 1960s and 1970s. Now the area of peatland forests that have reached maturity is almost 400,000 ha and it is expected to reach 700,000 ha within ten years (Saarinen, 2013).

Scots pine (Pinus sylvestris L.) is the most dominant tree species in poor and medium-productivity peatlands. In recently drained peatlands the natural regenera- 
tion of Scots pine stands was earlier recommended, and studies showed that it was generally successful (Lukkala, 1938; Heikurainen, 1954; Seppälä, 1966; Moilanen \& Issakainen, 1984). However, the water level drawdown due to drainage gradually changes the ground vegetation, which increases the coverage of forest moss species. These species are considered more difficult for seedling germination than Sphagnum mosses (Kaunisto, 1984; Kaunisto \& Päivänen, 1985; Saarinen, 2013). Sphagnum mosses prevent the formation of the litter layer on peatlands and form a good substrate for seedling germination. However, mosses disappear from efficiently drained peatlands already in the early phases of post-drainage succession (Place, 1955; Heinselman, 1957; Sarasto \& Seppälä, 1964; Wood \& Jeglum, 1984; Groot \& Adams, 1994; Saarinen, 2002). At the same time, the accumulation of tree and vegetation litter on top of the peat starts to form a socalled 'raw humus layer' which breaks the capillary connection between the ground water table and the seed bed (Kaunisto \& Päivänen, 1985; Saarinen \& Hotanen, 2000; Saarinen, 2013). This leads to reduced seedbed receptivity and an increased need for soil preparation. Thus, the planting of Scots pine seedlings in older drainage areas has been a commonly used regeneration method.

In older transformed drainage areas site preparation is seen as a prerequisite for successful establishment and leaving the soil unprepared is not considered a viable option (Kaunisto, 1984; Mannerkoski, 1975; Kaunisto \& Päivänen, 1985). Site preparation removes competing surface vegetation and the possible raw humus layer, and uncovers the original moist peat surface. The decision of which soil preparation method to use is one of the key issues in forest regeneration. Mounding has been the most common method, especially in drained peatland forests, and can be simultaneously associated with ditch network maintenance (Saarinen, 1997; Saarinen et al., 2013). Seedlings planted on mounds are not at risk of being waterlogged in rainy seasons. However, the vegetation layer, which is a major hindrance to the development of seedlings, can be removed also by scalping (a form of patch scarification done by an excavator). Scalping also maintains the capillary connection between the soil surface and the water table, thus preventing excessive drying of the peat, which may occur in mounds due to wind and sun exposure, especially during dry periods (Saarinen, 2013). However, in scalps, especially if they are too deep, the water level may rise too high during rainy seasons (Saarinen et al., 2013). Scalping could be more environmentally friendly compared to mounding, since it does not involve as severe soil disturbance as mounding. Furthermore, shallow scarification by rotavation can be used if the raw humus layer is shallow (Kaunisto \& Päivänen, 1985; Saarinen, 1993; Helenius \& Saarinen, 2013).

Stand regeneration after clearcutting is the most expensive investment in forest management. Seeding, if successful, is a less expensive method than planting. Additionally, scalping is considered less expensive than mounding in soil preparation. The profitability of forestry on peatlands is hampered by lower harvesting removals and higher harvesting costs than on mineral soils as well as additional costs such as ditch network maintenance and in some cases also fertilization. Concerning the afforestation of treeless swamps, Keltikangas \& Seppälä (1966) concluded that seeding may economically be the best alternative to planting. If successful, seeding or natural regeneration could thus be a very attractive alternative regeneration method instead of planting for minimizing regeneration costs.

The aim of this study was to investigate regeneration methods (planting or seeding) and soil preparation methods (no soil preparation, mounding, or scalping) on the regeneration results of Scots pine on drained peatlands. We hypothesized that 

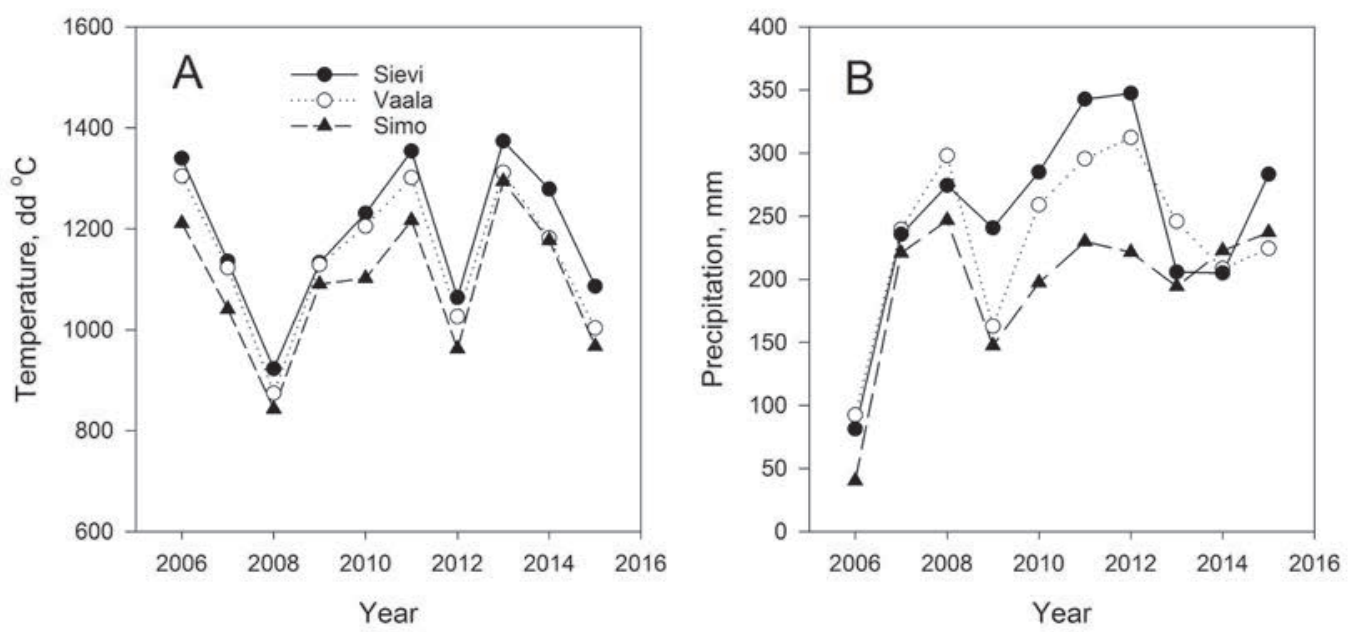

Figure 1. Annual temperature sum $\left(A\right.$, dd threshold value $\left.5^{\circ} \mathrm{C}\right)$ and precipitation $(B)$ in June-August 2006-2015 at the Sievi, Vaala and Simo experimental sites.

planting would lead to higher seedling density and faster development than seeding and that site preparation (scalping, or mounding) would increase the number and growth of Scots pine seedlings and result in higher stand stocking compared to no soil preparation.

\section{Materials and Methods}

\section{Study sites}

Three field experiments were set up in mature Scots pine stands in central and

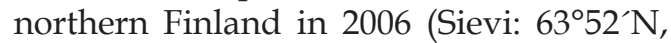
$24^{\circ} 19^{\prime} \mathrm{E}$; Vaala: $64^{\circ} 35^{\prime} \mathrm{N}$, $26^{\circ} 52^{\prime} \mathrm{E}$; Simo: $\left.65^{\circ} 54^{\prime} \mathrm{N}, 2^{\circ} 36^{\prime} \mathrm{E}\right)$. All sites had been initially ditched in the 1920s or 1930s and ditch network maintenance was done later (Sievi: 1965; Vaala: 1985; Simo: 1950s and 1987). The Sievi stand was fertilized with PK-fertilizer in 1965. The site type at Sievi and Vaala were Vaccinium vitis-idaea drained peatland forests and at the Simo site it was a Vaccinium myrtillus drained peatland forest according to Laine et al. (2012). Peat thickness exceeded $90 \mathrm{~cm}$ at all sites and the peat was composed of well-humified Carex-peat or Carex-Sphag- num-peat. The average (1984-2013, 30-year period) temperature sum (degree days, dd, $+5^{\circ} \mathrm{C}$ as the threshold) at the Sievi site was $1,119 \mathrm{dd}$, while at the Vaala site it was 1,079 $\mathrm{dd}$ and at the Simo site it was $1,022 \mathrm{dd}$. The 30-year average June-August precipitation at the sites was $195-215 \mathrm{~mm}$. The first summer following site preparation (2006) was exceptionally dry and warm. The second summer was average and the third (2008) summer was cold and wet (Figure 1). In all sites, seven growing seasons out of ten were warmer and wetter than the average 30-year period.

\section{Experimental design and treatments}

At the Sievi, Vaala and Simo sites 12 plots sized 1,928-8,235 $\mathrm{m}^{2}, 15$ plots sized 1,8102,190 $\mathrm{m}^{2}$ and 15 plots sized 1,500-2,520 $\mathrm{m}^{2}$, respectively, were established. For these plots, soil preparation treatments (control, scalping, and mounding) were randomly subjected, thus resulting in four replicates at the Sievi site, and five replicates at the Vaala and Simo sites. The soil preparation treatment plots were divided into two equal sub-plots. On each of the sub-plots, planting or sowing treatments were randomly applied. 
At all sites the sample plots were delineated in the field, and the area was clearcut at the Sievi and Vaala sites in October 2005, and in April 2006 at the Simo site. The site preparation treatments included: 1) unprepared control treatment, 2) scalping, and 3) mounding. Scalping was done with the scoop of an excavator by removing a very thin layer of the topsoil. Mounding was done by digging a shallow ditch and lifting the peat to the soil surface in low mounds. At the Sievi site, the preparation was done in November 2005. At the Vaala site, mounding was done in November 2005, and scalping was done in early May 2006. At the Simo site, soil preparation was done in late May, 2006. One-year-old containerized Scots pine seedlings of local origin were planted at a density of 2,000 seedlings per hectare in May-early June in 2006 at all the experimental sites. In each sowing spot (2,000 per ha), approximately 25 Scots pine seeds were sowed at the same time as the planting of the seedlings was done.

\section{Field measurements - annual follow-up at the Sievi site}

At the Sievi site, the number and height of the living, planted and sown Scots pine seedlings were monitored every year after the growing season for the first six years and final measurements were made 10 years from the establishment of the experiment. Two circular seedling inventory sample plots of $50 \mathrm{~m}^{2}$ in size were established in the middle of the sown or planted treatment plots and marked with plastic tubes. Sowing spots were small and had been marked in the field in order to decrease the risk of including naturally regenerated seedlings. In the sown plots the number of living Scots pine seedlings was counted, and the height of the tallest seedling was measured. Additionally, all naturally regenerated seedlings over $3 \mathrm{~cm}$ in height were inventoried according to their tree species. These measurements were used in analyzing the development of the seedling numbers after planting.

\section{Field measurements - regeneration survey}

Ten years after the establishment, a measurement survey was conducted at all three sites (Sievi, Vaala and Simo) to determine the success of the regeneration. At the Sievi site, the same seedling inventory plots as in the follow-up study were examined. At the Vaala and Simo sites, two $20 \mathrm{~m}^{2}$ circular seedling inventory sample plots were established in every treatment plot. The number and height of the living planted seedlings were measured. For the seedlings on the sown treatment plots, the height of the tallest seedling was measured in each sowing spot. Additionally, the number of naturally regenerated seedlings and their height were measured by species. Damage to the planted seedlings was assessed. The number of crop seedlings (dominant competitive seedlings of good quality being able to form commercial stems after thinning or in the final cut) were calculated on the basis of the measurement results. The target was to achieve 2,000 crop seedlings per ha on each plot, which is the target density for good regeneration of Scots pine (Äijälä et al., 2014). The selected crop seedlings had to be primarily planted or sown Scots pine seedlings. If there were not enough planted (or sown) Scots pine seedlings then naturally regenerated Scots pine seedlings were accepted, and in the next step naturally regenerated Norway spruce (Picea abies (L.) H. Karst.) seedlings. If the target of 2,000 seedlings still failed to be reached, birch (Betula spp.) seedlings were also included.

\section{Statistical methods}

The mean seedling numbers (for the total and crop seedlings) for each species were calculated according to the experimental sites, regeneration methods (sowing, planting) and site preparation treatments (control, scalping, mounding). The differences in the average seedling numbers per ha according to the site preparation treatments in each location were calculated and 
graphically compared. Differences in the seedling numbers and heights at the 10year time point were tested in the whole dataset with an analysis of variance using the experiment, soil preparation treatment and regeneration method as fixed effects and the block as a random effect. The homogeneity of variances was tested with Levene's test and, when needed, variance-stabilizing transformations were made. When testing values in percentage, arc sine, transformed values were used.

\section{Results}

\section{Sievi site follow-up study}

The number of living planted seedlings at the Sievi experimental site remained high on mounded plots but started to decline especially on the control plots and also on the scalped plots after the second growing season (Figure 2A). The decline was fast especially on the control plots with only 525 seedlings per ha remaining after three growing seasons. This was attributed mostly to damage caused by pine weevils (Hylobius abietis (L.)). After the first grow- ing season, $46 \%$ of the seedlings planted on unprepared soil had pine weevil damage, while none of the seedlings planted on prepared soil suffered from this. The number of planted seedlings on scalped plots also declined and after three growing seasons it dropped to 1,050 seedlings per ha.

After the first growing season, the number of Scots pine seedlings in sowing spots with at least one living seedling was 1,175, 675 and 450 seedlings per ha for the control, scalping and mounding treatments, respectively (Figure 2B). The number of sowing spots with at least one seedling after 10 years was the lowest on the scalped plots (200 seedlings per ha).

The number of naturally regenerated seedlings increased in all treatments annually, peaking at six years from establishment at 26,000 seedlings per ha in the control and 36,000-37,000 seedlings per ha in the scalped and mounded peat plots (Figure 3A). The majority of the seedlings were downy birch Betula pubescens Ehrh. (Figure 3B). The number of Scots pine seedlings increased from 31 seedlings per ha after the first growing season to 5,300 seedlings per ha after the $10^{\text {th }}$ growing season.
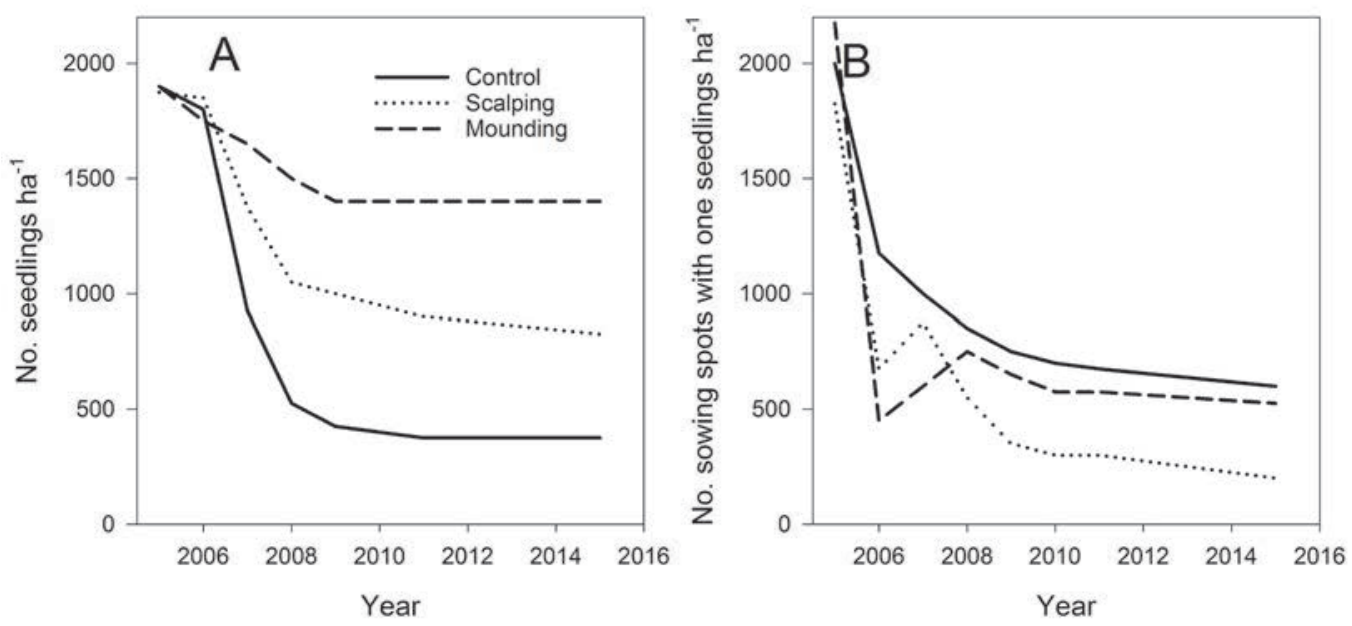

Figure 2. Development of the number of living planted Scots pine seedlings (A) and the number of sowing spots with at least one living seedling (B) at the Sievi experimental site. 

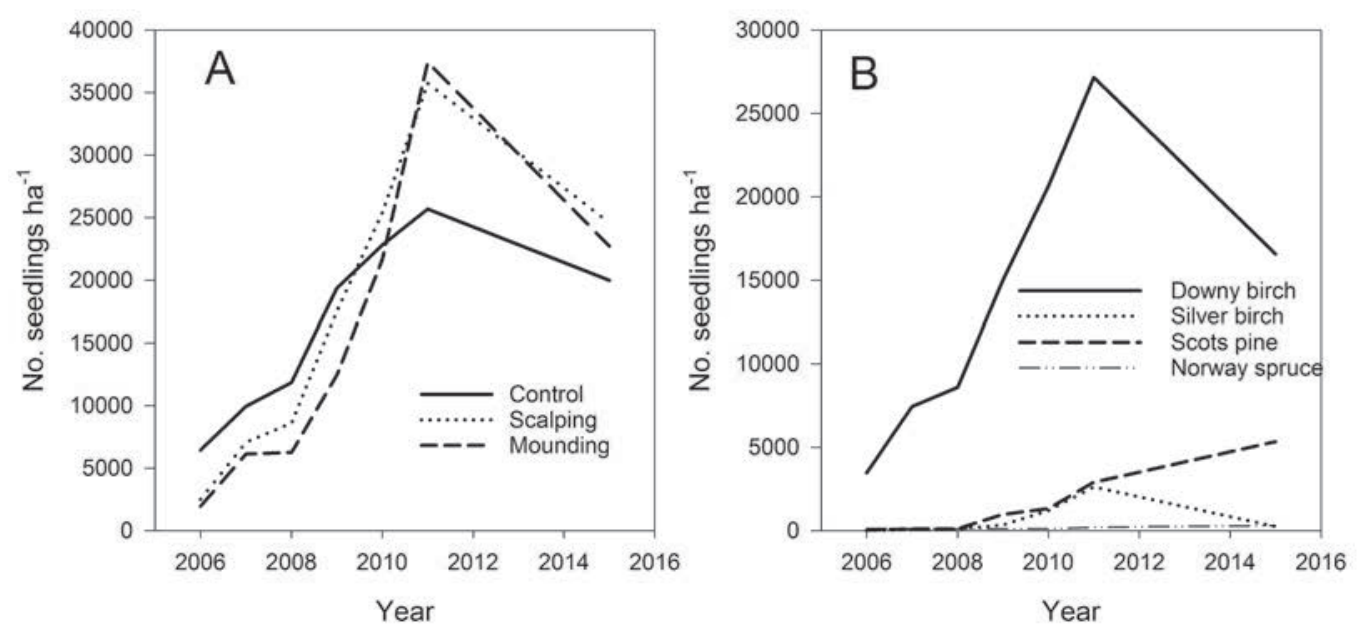

Figure 3. Development of the number of naturally regenerated seedlings according to soil preparation treatments (A) and by species (B) at the Sievi experimental site.

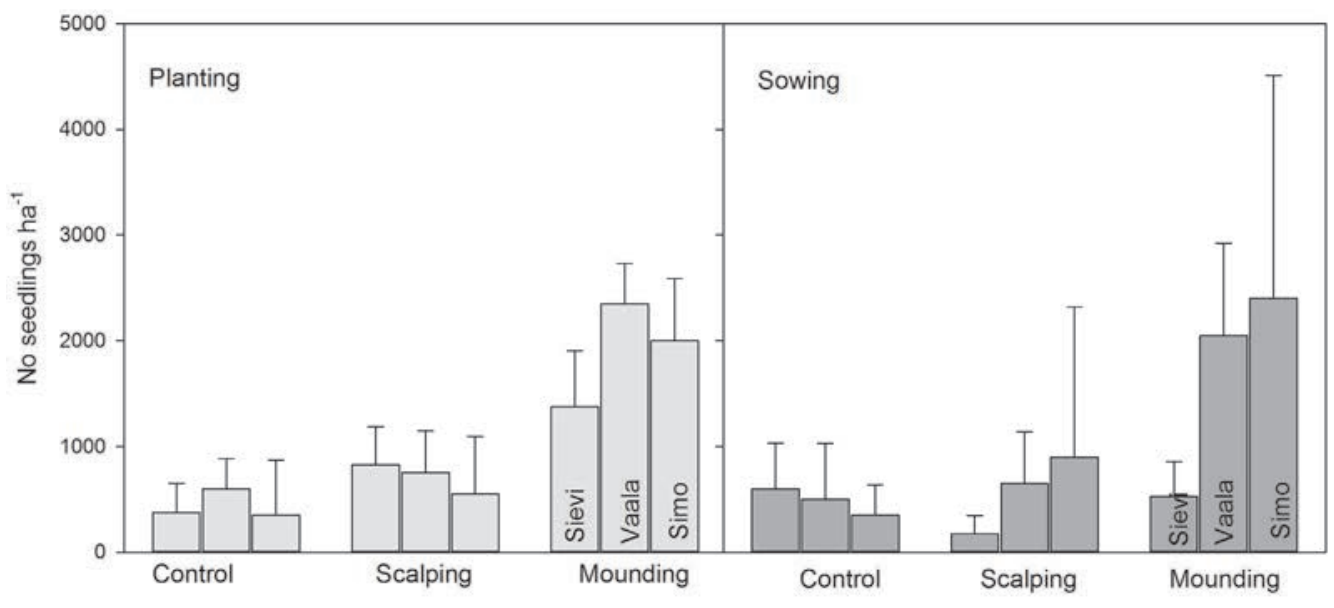

Figure 4. The number of planted and sown Scots pine seedlings in the study areas (at the Sievi, Vaala, and Simo sites). In each sowing spot only one seedling was accepted. The standard deviation is marked inside the bars.

\section{Regeneration result at year 10}

\section{The overall number of seedlings}

The establishment method (planting/sowing) did not affect the number of Scots pine seedlings at the 10-year time point from planting or sowing at Simo and Vaala experiments, but at Sievi, sowing gave poorer results than planting (one living seedling in each sowing spot accepted) (Figure
4). This resulted in significant experiment and establishment method interaction ( $p$ $=0.009)$. The experiments differed in the number of living seedlings ( $p<0.001$ ) and the Sievi site had the lowest number of seedlings. The soil preparation method had a significant effect on the number of seedlings ( $p<0.001)$. In addition, there was an almost significant experiment $x$ soil preparation interaction $(\mathrm{p}=0.021)$. 
The best result was obtained by mounding and the poorest when no soil preparation was done.

After 10 growing seasons, the number of naturally regenerated Scots pine and birch seedlings varied between the three study areas $(p<0.001)$, but site preparation had no effect on the number of Scots pine $(p=0.408)$, Norway spruce $(p=0.156)$, and birch $(\mathrm{p}=0.246)$ seedlings (Figure 5). The Sievi and Vaala sites had an almost equal number of naturally regenerated Scots pine seedlings, although the number was low at the Simo site. The number of Norway spruce seedlings was highly variable: at the Simo site 3,800 seedlings per ha were counted, but at the Vaala site only 70 seedlings per ha were found. The highest number of birch seedlings was found at the Vaala site (31,100 seedlings per ha) and the lowest numbers occurred at the Simo site (7,900 seedlings per ha). Additionally, some other tree species such as aspen and rowan were noted at some of the sites. The total number of naturally regenerat- ed seedlings was lowest at the Simo site $(12,800$ seedlings per ha) and highest at the Vaala site (37,000 seedlings per ha).

\section{Number of crop seedlings}

The average number of crop seedlings in all experiments and soil preparation treatments reached the target of 2,000 seedlings per ha regardless of the establishment method (planting/sowing) when naturally regenerated seedlings were also included (Figure 6). However, there were differences in the number of planted/sown Scots pine seedlings in the crop seedlings. The proportion of planted/sown Scots pine crop seedlings was lowest in the unprepared soil (18-30\%), with the minimum number at the Sievi site on scalped peat, where there were only $9 \%$ of the sown crop pines out of 2,000 seedlings per ha. Soil preparation, especially mounding, increased the number of planted/sown Scots pine crop seedlings in all the experiments except at the Sievi site where on sown areas their number was highest on unprepared soil.

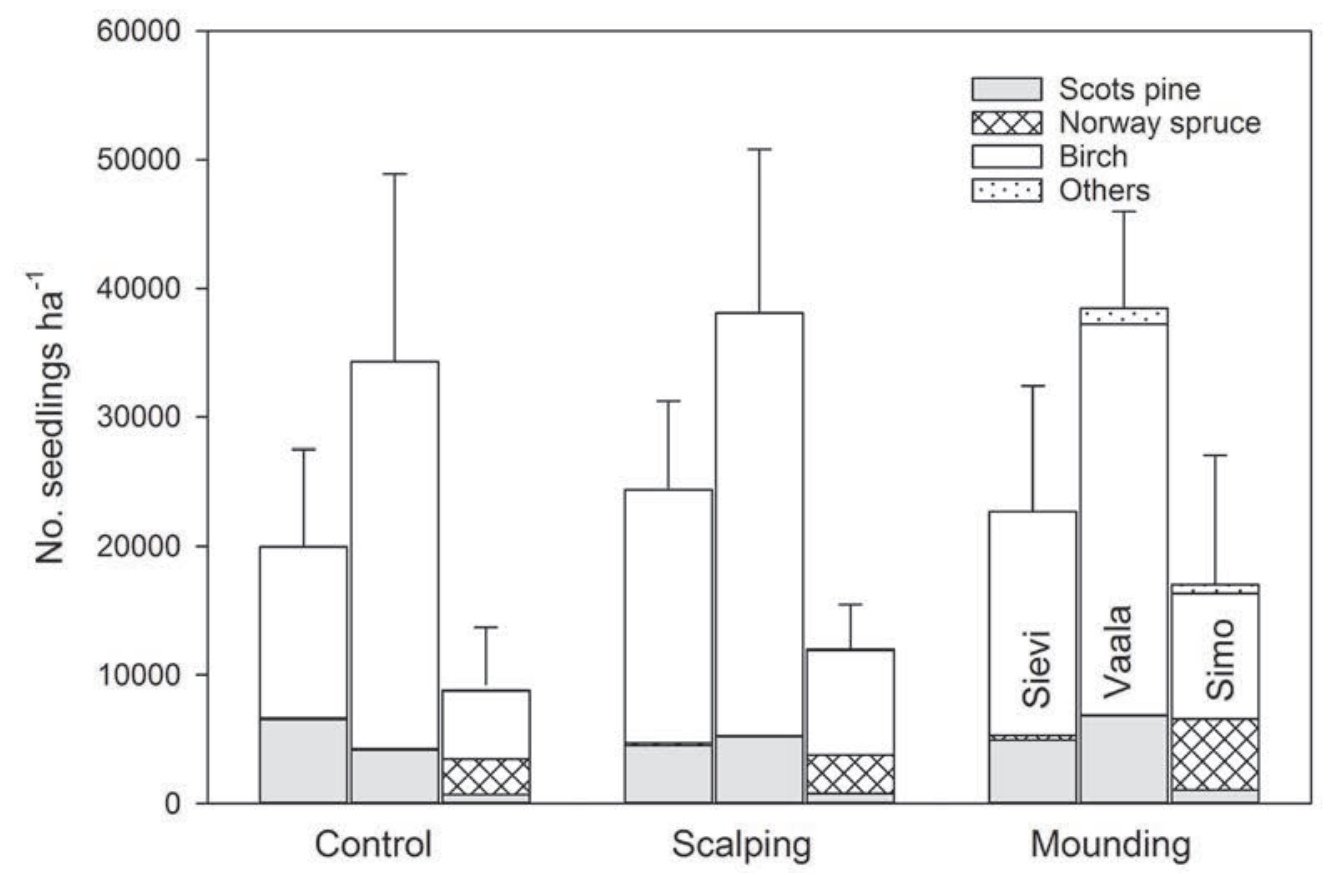

Figure 5. The number of naturally regenerated seedlings in the study areas (at the Sievi, Vaala, and Simo sites). The standard deviation is marked inside the bars. 


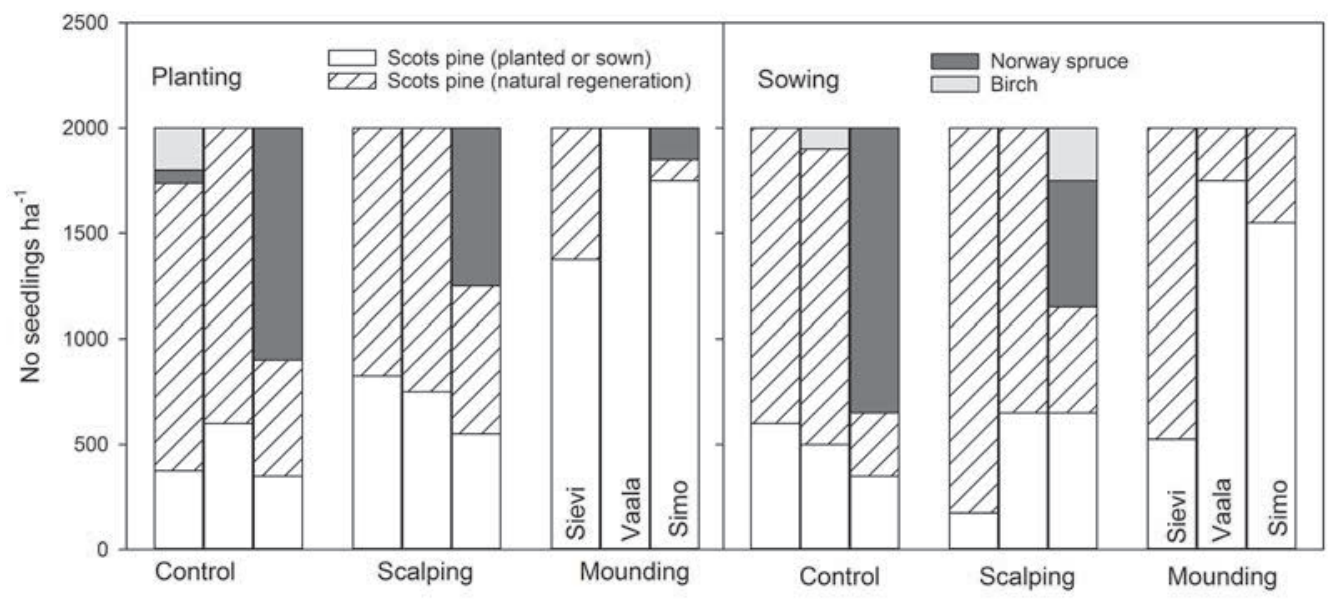

Figure 6. The number of crop seedlings in the study areas (at the Sievi, Vaala, and Simo sites).
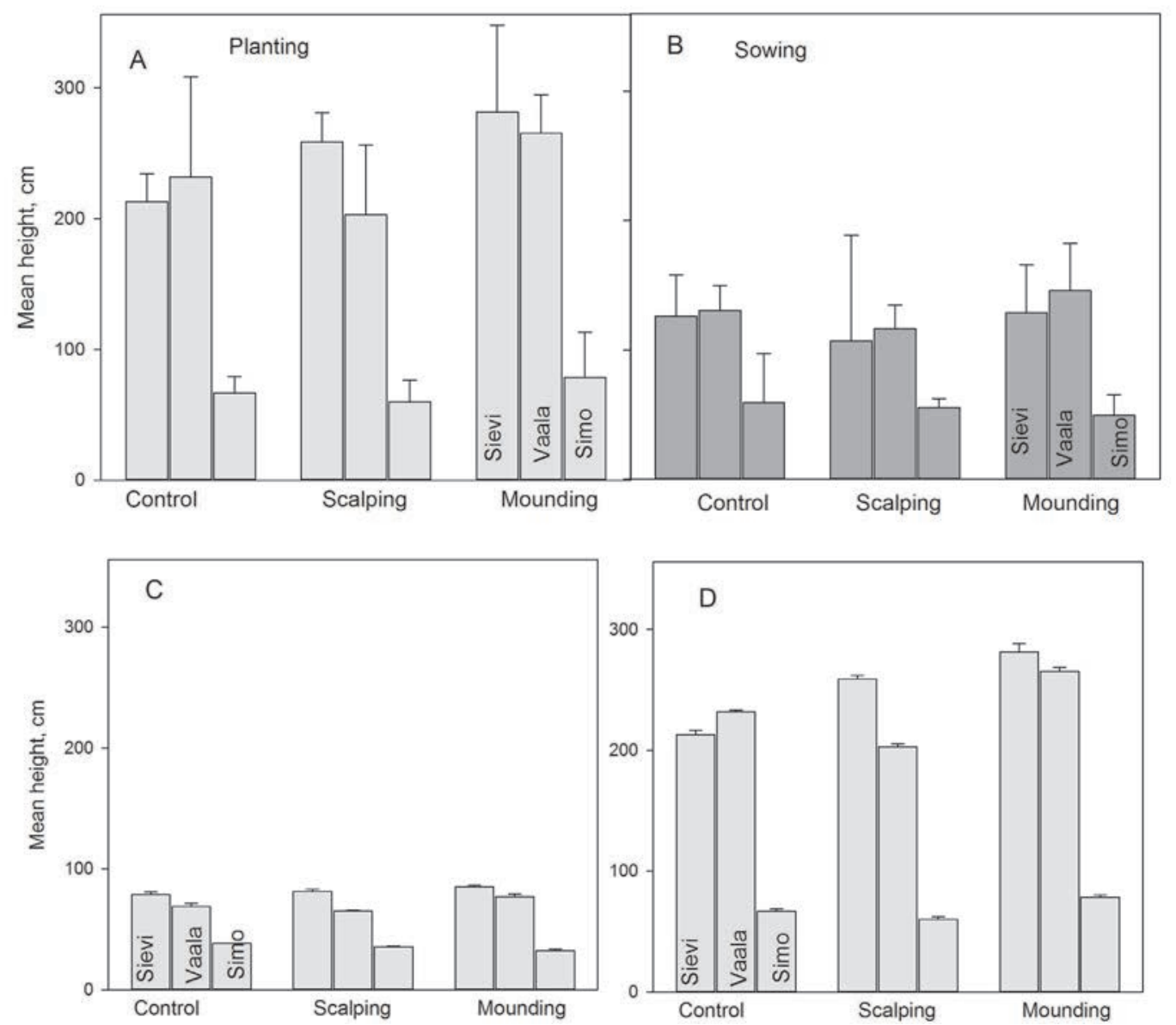

Figure 7. The mean height of planted (A), sown (B) and naturally regenerated $(C)$ Scots pine seedlings and naturally regenerated downy birch seedlings (D). The standard deviation is marked inside the bars. 
Scalping increased the number of planted/ sown Scots pine crop seedlings by $8-23 \%$ units compared to the control treatment, except for the sown treatment at the Sievi site. Mounding was the most effective treatment in all experiments and increased the number of Scots pine crop seedlings by $50-70 \%$ units, with the exception of the sown treatment at the Sievi site. When naturally regenerated Scots pine or Norway spruce seedlings were accepted as crop seedlings, almost all treatments reached the target of 2,000 seedlings per ha. Only in three cases, 100-250 downy birch seedlings were needed to reach the final target.

\section{Height of the seedlings}

After 10 growing seasons the mean height of both artificially (planted or sown) and naturally regenerated Scots pine seedlings as well as naturally regenerated downy birch seedlings varied significantly between the study sites $(p<0.001)$ (Figure 7A-C). At the Simo site, seedlings were the shortest. The regeneration method had a significant effect $(p<0.001)$ on the height of Scots pine seedlings (Figure 7A). The height of sown seedlings was 48\%, 56\% and $80 \%$ of the height of the planted seedlings at the Sievi, Vaala, and Simo sites, respectively. Furthermore, the height of naturally regenerated Scots pine seedlings was $48 \%, 86 \%$ and $55 \%$ shorter compared to the height of sown seedlings at the Sievi, Vaala and Simo sites, respectively. The low mean height of birch seedlings is due to their high number: i.e., there were many small seedlings which reduced the mean height. The soil preparation method did not affect the height of planted or sown Scots pine seedlings $(p=0.092)$, naturally originated Scots pine seedlings $(p=0.644)$ or naturally originated birch seedlings $(\mathrm{p}=$ 0.290). There was also significant interaction between experiment and soil preparation treatment $(\mathrm{p}<0.001)$. This was largely due to the Simo experiment where the soil preparation did not have a significant effect on the height of pines (Figure 7A). Moose (Alces alces L.) had severely browsed the Scots pine seedlings at the Simo site (Figure 8), which reduced their height.

\section{Seedling damage}

No initial seedling damage could be detected in the inventory carried out ten years after planting or sowing. However, some significant moose damage occurred (Figure 8) depending on the experiment (significant experiment effect $p=0.039$ ). On

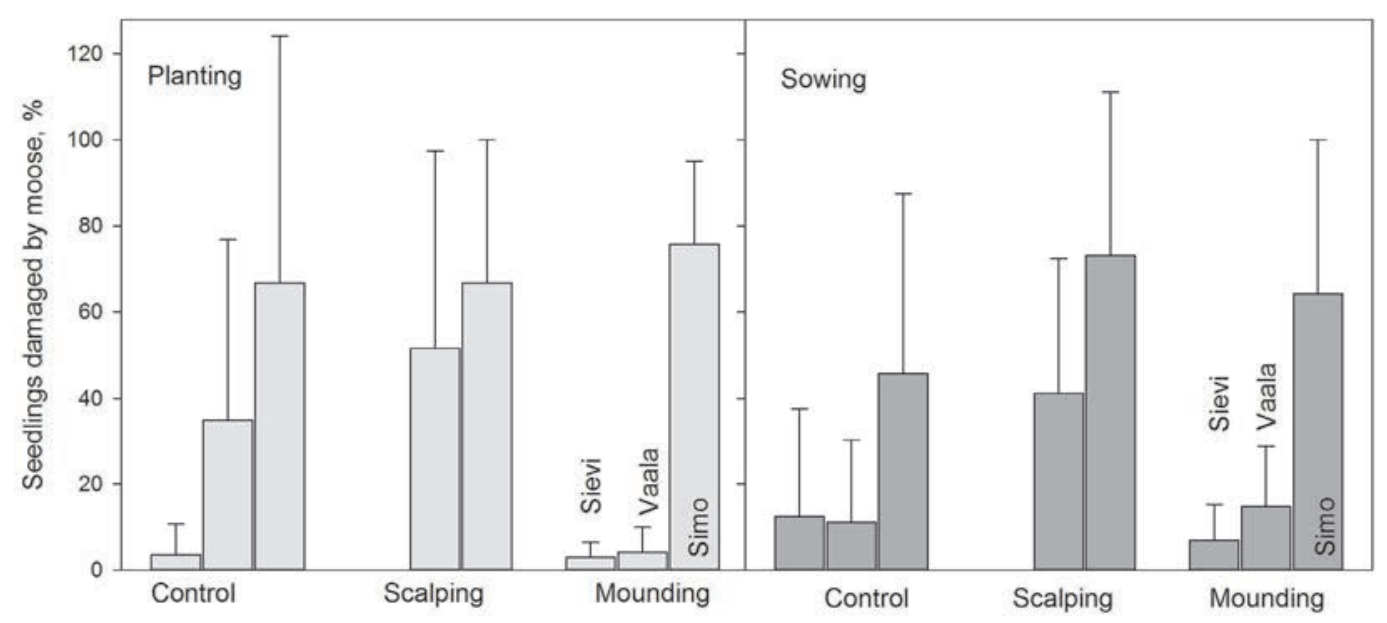

Figure 8. Share of Scots pine crop seedlings damaged by moose. The standard deviation is marked inside the bars. 
the other hand, there was no difference in the amount of damage between planted or sown seedlings $(p=0.578)$ or the soil preparation $(p=0.495)$ method. Especially at the Simo site, Scots pine seedlings suffered considerable moose damage. The share of damaged seedlings at the site amounted to $65 \%$. At the Vaala site, $23 \%$ of seedlings were damaged by moose compared to the respective $4 \%$ at the Sievi site. $21 \%$ of the planted and $22 \%$ of the sown Scots pine seedlings were assessed as damaged due to the competing growth of downy birch trees at the Sievi site, and at the Vaala site $0.6 \%$ of the planted and $6 \%$ of the sown seedlings suffered from similar damage. At the Vaala site, $4 \%$ of the Scots pine seedlings were assessed having pine twisting rust (Melampsora pinitorqua Rostr.).

\section{Discussion}

We studied the effect of soil preparation and regeneration methods (planting or sowing) on the regeneration of Scots pine on drained peatlands. We were interested in the overall regeneration result defined as the number of crop seedlings after ten years from planting or sowing. A sufficient regeneration result was obtained at all sites and with all of the studied treatments in terms of silvicultural recommendations (Äijälä et al., 2014). However, the number of planted or sown Scots pine crop seedlings was low on non-prepared plots and on scalped plots, but even with these treatments the target density of crop seedlings $(2,000$ per ha) was achieved when naturally regenerated Scots pine or Norway spruce seedlings were also accepted as crop seedlings. In three cases, 100-250 downy birch seedlings were needed to reach the target of 2,000 seedlings per ha.

After ten years the number of surviving Scots pine seedlings was independent of the establishment method (planting or sowing; only one seedling per sowing spot accepted) at two of the study sites.
At the Sievi site, sowing gave poorer results than planting. However, it seems that in terms of the number of surviving Scots pine seedlings, planting and seeding could be alternative methods. This study confirms earlier results (e.g. Mannerkoski, 1975; Kaunisto, 1984; Moilanen \& Issakainen, 1984; Kaunisto, 1986; Hånell, 1992: Moilanen et al., 1995) that soil preparation is needed in order to achieve a satisfactory result in artificial regeneration. Without soil preparation the number of original planted or seeded seedlings was very low (350-600 per ha). On scalped plots the number of seedlings was generally only a little higher (550-900 per ha) and at the Sievi site, scalping did not increase the number of seeded seedlings at all. On the mounded plots the number of original planted or seeded seedlings was high $(1,325-2,350$ per ha), with the exception of the seeded plots at the Sievi site where mounding did not increase the number of seeded seedlings. Similarly, Pearson et al. (2011) reported that the survival of Scots pine seedlings was $90 \%$ on mounded plots and $33 \%$ on scalped plots three years after planting. In this study, the number of naturally born Scots pine seedlings was high and not affected by the soil preparation treatments (at the Vaala and Sievi sites, there were $5,300-5,400$ seedlings per ha, while at the Simo site, there were 850 seedlings per ha). Also a high number of downy birch seedlings $(7,900-31,000$ per ha) was found in the regeneration areas regardless of the soil preparation method.

The average number of crop seedlings reached the target of 2,000 seedlings per ha in all treatments. Thus, the soil preparation or establishment methods (planting or sowing) did not affect the total number of crop seedlings when naturally born seedlings were also included. However, the share of planted or sown seedlings of the total number of crop seedlings considerably varied among the soil preparation treatments. On unprepared soil, only $23 \%$ of the crop seedlings originated from planting or 
sowing and the rest were naturally regenerated seedlings. Scalping would have led to an almost as poor result if naturally born seedlings were not included. The share of planted or seeded Scots pines on scalped plots was on average $30 \%$ out of 2,000 crop seedlings per ha, the rest being naturally regenerated seedlings. Therefore, less than one third of the seedlings originated from planting or sowing.

The best result was achieved with mounding. If the sown plots at the Sievi site were excluded, the average share of planted or sown Scots pines would have been $84 \%$ of the total of 2,000 crop seedlings per ha. At the Sievi site, mounding failed to increase the number of sown seedlings. The number of sown seedlings was low already after the first growing season in the follow-up study in the Sievi experiment. The majority of the naturally regenerated seedlings accepted as crop seedlings were Scots pines or also Norway spruces at the Simo site. Thus, the share of downy birch needed to reach the target of 2,000 seedlings per ha was low and only in three cases it was 100-250 downy birch seedlings per ha. Earlier we have shown that natural regeneration can also yield a high share of crop seedlings even without soil preparation in eight years if downy birch seedlings were also included (Hytönen et al., 2019). However, in natural regeneration with seed trees, soil preparation considerably increased the numbers of Scots pine crop trees, hence leading to a reduced share of downy birches among crop seedlings. Consequently, in natural regeneration without soil preparation, a much higher birch admixture was needed to reach full density (Hytönen et al., 2019), which may lead to stands of lower value reducing the financial outcome of the next generation of trees. Kaunisto (1984) found that soil preparation (scalping or mounding) increased the number of pine-occupied sowing spots by two to four folds after one to two years from sowing in a Scots pine regeneration experiment.
Contrary to the Vaala and Simo experiments at the Sievi site, seeding failed to increase the number of seedlings on prepared (mounding, scalping) soil. At the Sievi site, the number of seeding spots with at least one seedling after the first growing season was very low (mounding; 450 seedlings per ha, scalping up to 675 seedlings per ha). The very dry first summer could have increased the mortality of seedlings on the mounded plots, but since almost similar weather conditions prevailed at other sites as well this was probably not the main reason. Since at the Simo site, sowing was done only a week after soil preparation the mounded soil was still moist resulting in good survival. On mounds the effect of drought is highly dependent on the type and bulk density of the peat. During extended dry periods, the outer portions of mounds dry rather quickly resulting in a crust several centimeters thick. Upon drying to a specific water content, the peat becomes water-resistant, i.e., hydrophobic, after which it rewets very slowly. In practice, hydrophobicity means that the dry, crusty peat mounds in the regeneration area require long-lasting rainfall in order to become rewetted (Saarinen et al. 2013). According to some rough visual observations at the Sievi site, quite many of the mounds consisted of poorly decomposed Carex-peat which is susceptible to excessive desiccation. This might be one possible reason for the poor sowing result on mounds at the Sievi site compared to that in the other experiments. However, also high seed predation at the Sievi site could explain the poor outcome of seeding. Seed predation on prepared soil can jeopardize some seeding operations (Nilsson \& Hjältén, 2003). Vegetation (as in the control treatment) decreases the risk of seed predation due to the fact that covered soil (vegetation, unprepared soil, cutting residues) gives shelter to the seeds (Helenius et al., 2015). Also, covering seeds immediately after seeding is seen as a cost-effective way to reduce seed predation and increase seedling emergence (Heikkilä, 1977; Nilsson \& Hjältén, 2003). 
The results of this study suggest that naturally established Scots pine seedlings gradually fill up the regeneration area, although no artificial seeding or planting is conducted. However, the distance to forest edge and its tree species composition affect natural regeneration and its spatial distribution in clearcut areas. Even in the control treatments without soil preparation a very high total number of seedlings was found when 10 years had passed since regeneration. This stresses the good natural susceptibility of peat soils for seedling germination, which enables continuous Scots pine and Norway spruce seedling establishment for at least ten years and downy birch establishment for six years after harvest (Figure 3). It also raises a question of whether investments in soil preparation and seeding or planting pay off if a good regeneration result without any investments can be achieved in the same time. In order to cover the higher investment costs of artificial regeneration and soil preparation, the share of Scots pines as crop seedlings should be higher, the height development of planted seedlings on prepared soil should be clearly faster or the planted seedlings should otherwise be superior (e.g. originating from genetically improved seed) compared to natural regeneration without soil preparation.

Pine weevils (Hylobius abietis (L.)) caused significant damage in the experiment at the Sievi site and probably also in other experiments after planting on unprepared soil. The damage ( $46 \%$ of seedlings) was likely the cause for the fast decline in the number of living planted seedlings on unprepared soil. Soil preparation considerably reduced pine weevil damage not just on mineral soils but also on peatlands one year after planting (Luoranen \& Viiri, 2012). Thus, the planting of Scots pine seedlings without soil preparation, even though they have been treated with an insecticide, is questionable. Pearson et al. (2011) found pine weevil damaged Scots pine seedlings even in scalped and mounded areas, with the damage being much more substantial on scalped plots. At the age of ten years both the planted Scots pine seedlings and seedlings originating from sowing had suffered from moose damage, especially at the Simo site (65\% of seedlings). Additionally, at the Sievi site, damage caused by the competing growth of downy birches was noted.

Generally, soil preparation is expected to increase the height growth of seedlings due to better aeration of the mounds, higher temperature, and less competition from ground vegetation. This assumption was confirmed by the results of Mannerkoski (1975) and Kaunisto (1984) showing that the height growth of Scots pine seedlings at 4-5 years from planting was higher on mounded plots than on non-mounded plots. In this study, the mean height advantage of planted seedlings on mounds $(69 \mathrm{~cm}, 33 \mathrm{~cm}$, and $12 \mathrm{~cm}$ at the Sievi, Vaala, and Simo sites, respectively) over seedlings growing on unprepared soil was not statistically significant. Also, according to Silfverberg (1995), mounding did not significantly increase the height of seedlings on nutrient-poor drained peatlands after 7 growing seasons. Furthermore, Pearson et al. (2011) found no differences in seedling height between mounds and unprepared planting spots three years from planting. The significant height advantage of planted seedlings over the sown seedlings in our study was partially due to the one-year age gap of the planted seedlings.

Mounding produced better results in this study than scalping when the regeneration results were assessed as the total number of planted or sown seedlings or the number of Scots pine crop seedlings. The poor outcome of planted and seeded seedlings in the scalps was probably related to their filling with water during the third especially wet growing season. Such is the case particularly in years when a fluctuating water table level in a scalped regeneration area rises during a late summer (Saarinen, 2013). Excess moisture in scalps has also been fatal in natural regeneration 
(Hytönen et al., 2019) as well as in planting (Pearson et al. 2011), but it does not cause problems at coarse mineral soil sites where water perforates into the soil. In well-humified Carex-dominated peat, as in the study sites, the water conductivity is low, which may transform scalps into water ponds after longer periods of rain. With scalping the water table may also be too close to the scalp surface for young seedlings to grow efficiently (Mueller-Dombois, 1964; Lieffers \& MacDonald, 1990; Pearson et al., 2011; 2013). Scalping could also increase the risk of frost heaving for small seedlings after planting or seeding, especially when the peat is well humified (Kaunisto \& Päivänen. 1985 citing Multamäki, 1939).

However, in natural regeneration, mounding and scalping have produced equal results (Hytönen et al., 2019). This may be due to the longer establishment phase in natural regeneration using the seed tree method. The most rapid increase in the seedling number takes place within three years of treatment (Hökkä et al., 2016), but pine seedlings can emerge even 6-7 years from seed tree cuttings and site preparation (Saarinen, 2002). The weather conditions vary annually, and scalps may be good surfaces for establishment in dry seasons. In mounding, seeds establish themselves on an elevated surface, which is generally not too moist for seedling germination. The mound surface can, however, become too dry and prove an unfavorable substrate for seeds to germinate in (Saarinen, 2013). In this study, the very dry first summer was probably the reason for the low survival of sown seedlings due to excessive desiccation of the surface peat in mounds. However, planted seedlings fared much better during the dry summer probably because their roots were in the moist peat deeper in the mounds. Mounding has also the advantage of restricting competition from ground vegetation more effectively and for a longer time than lighter soil preparation methods, such as scalping (Mannerkoski, 1975; Moilanen \& Issakainen, 1981; 1984; Saarinen et al., 2009). This study strengthened the evidence of the positive effects of mounding for the regeneration of Scots pine trees by planting or sowing. Even on nutrient-poor drained peatlands which are subject to slow vegetational changes, mounding considerably increased the number of seedlings after sowing (Silfverberg, 1995).

In line with our earlier studies (Hytönen et al., 2019), besides increasing the abundance of Scots pines, site preparation also seems to increase the number of downy birch seedlings. This has been observed in other studies, as well (e.g. Moilanen \& Issakainen, 1981; 1984; Silfverberg, 1995; Saarinen, 2002). The dense stocking of downy birch increases the need for young stand treatment, and if neglected, the further development of pine regeneration becomes hampered.

Similarly to some other studies (e.g. Saarinen, 2002; 2013), attempts to generalize the results of site preparation effects come up against the uncertainty inflicted by the variation in soil moisture. In the light of this study, the risk of drought on mounds during dry seasons is a smaller problem for regeneration than the possibility of excess moisture in scalps during rainy summers and sometimes also summers with average precipitation. Thus, it is better to restrict the use of scalping in natural regeneration where seedlings emerge over several years (Hökkä et al., 2016) only and to make mounds when using artificial regeneration. All methods of site preparation have increased the number of Scots pine seedlings on drained peatlands, excluding such drained peatlands where original Sphagnum moss vegetation still dominates the ground vegetation (Saarinen, 2002).

\section{Conclusions}

This study suggests that seeding and planting can achieve similar regeneration results when the number of crop seedlings is considered but that the height of planted seedlings is greater than that of seeded seedlings 
at a ten-year time point. Mounding proved to be a superior soil preparation treatment, leading to a higher number of surviving planted seedlings or seedlings in seeding spots. However, mounding did not increase significantly the height growth of the seedlings. On the other hand, scalping only had small advantages compared to non-prepared soil. The poor result of the scalping treatment was probably due to the scalps filling with water during rainy seasons. It is better to restrict the use of scalping to natural regeneration in which seedlings emerge over several years. Since natural regeneration was abundant and when naturally regenerated seedlings were also included, a target density of 2,000 seedlings per ha was achieved with all treatments. On two of the study sites the number of naturally born Scots pine seedlings (even on non-prepared plots) was so high $(4,200-6,500$ per ha) that reforestation would have been secured even without any planting or seeding. Some years after clearcutting the number of downy birch seedlings was high, suggesting an increasing need for young stand tending and precommercial thinning.

Acknowledgments. Several people from the Luke Kannus, Oulu and Rovaniemi units took part in the field work. We would like to express a special thanks to Seppo Vihanta who helped with calculations. We also wish to thank everybody who contributed to this project. This study received funding from the project 'Sustainable management of peatland forests: focus on regeneration' at the Natural Resources Institute Finland.

\section{References}

Äijälä, O., Koistinen, A., Sved, J., Vanhatalo, K., Väisänen, P. (eds.). 2014. Recommendations for good forest management 2014. (Hyvän metsänhoidon suositukset 2014). Metsätalouden kehittämiskeskus Tapio. 264 pp. Available online: https://www.metsanhoitosuositukset.fi/ wp-content/uploads/2016/08/Metsanhoidon_ suositukset_Tapio_2014.pdf. (In Finnish).
Groot, A., Adams, M.J. 1994. Direct seeding black spruce on peatlands: fifth-year results. - Forestry Chronicle, 70(5), 585-592. http:// dx.doi.org/10.5558/tfc70585-5.

Hånell, B. 1992. Forest regeneration on highly productive peatlands - planting of Norway spruce on clearcut area and under sheltertrees. (Skogsförnyelse på högproduktiva torvmarker - plantering av gran på kalhygge och under skärmträd). - Report 34. Umeå, Swedish University of Agricultural Sciences, Department of Silviculture. 71 pp. (In Swedish).

Heikkilä, R. 1977. Destruction caused by animals to sown pine and spruce seed in North Finland. (Eläimet kylvetyn männyn ja kuusen siemenen tuhoojina Pohjois-Suomessa). Communicationes Instituti Forestalis Fenniae, 89(5), 1-35. Available online: http://urn.fi/ URN:NBN:fi-metla-201207171122. (In Finnish with English summary).

Heikurainen, L. 1954. Regeneration of Scots pine stands on peatlands using clearcutting. (Rämemänniköiden uudistaminen paljaaksihakkausta käyttäen). - Acta Forestalia Fennica, 61(27). 21 pp. https://doi.org/10.14214/ aff.7439. (In Finnish).

Heinselman, M.L. 1957. Living Sphagnum found most favorable seedbed for swamp black spruce in Minnesota study. - Technical Note, No. 504. USDA Forest Service, Lake States Forest, Experiment Station. 2 pp.

Helenius, P., Himanen, K., Nygren, M., Vaahtera, E., Ylioja, T. 2015. Norway Spruce and Scots pine cone and seed damage. (Kuusen ja männyn käpy- ja siementuhot). Suonenjoki, Luonnonvarakeskus. 124 pp. Available online: http:/urn.fi/urn:isbn:978-952-326-041-2. Finnish).

Helenius, P., Saarinen, M. 2013. Regeneration result of excavator-mounted rototiller in direct seeding of Scots pine on forestry-drained peatland. - Scandinavian Journal of Forest Research, 28(8), 752-757. http://dx.doi.org/1 $0.1080 / 02827581.2013 .844849$.

Hökkä, H., Hytönen, J., Saarinen, M. 2016. The effect of scalping on seedling establishment after seed tree cutting of Scots pine stands in drained peatlands in northern Finland. Scandinavian Journal of Forest Research, 31(2), 166-174. http://dx.doi.org/10.1080/02827581.2015 .1105285 .

Hökkä, H., Kaunisto, S., Korhonen, K.T., Päivänen, J., Reinikainen, A., Tomppo, E. 2002. Peatland forests in Finland 1951-1994). (Suomen suometsät 1951-1994). - Metsätieteen aikakauskirja, 2B, 201-357. https://doi. org/10.14214/ma.6242. (In Finnish).

Hytönen, J., Hökkä, H., Saarinen, M. 2019. The effect of site preparation on seed tree regeneration of drained Scots pine stands in Finland. - Baltic Forestry, 25(1), 132-140. https://doi.org/10.46490/vol25iss1pp132. 
Kaunisto, S. 1984. Regeneration of peatlands forests in older drained peatlands. (Suometsien uudistaminen turvekangasvaiheessa). Metsäntutkimuslaitoksen tiedonantoja, 137, 7-21 Available online: http://urn.fi/ URN:NBN:fi-metla-201207202003. (In Finnish).

Kaunisto, S. 1986. Preliminary results from high efficiency forest regeneration experiments on peatlands. (Alustavia tuloksia metsän tehoviljelykokeista turvemailla). - Folia Forestalia, 619, 1-16. (In Finnish with English summary).

Kaunisto, S., Päivänen, J. 1985. Forest regeneration and afforestation on drained peatlands. A literature review. (Metsänuudistaminen ja metsittäminen ojitetuilla turvemailla. Kirjallisuuteen perustuva tarkastelu). - Folia Forestalia, 625, 1-75. Available online: http:/ / urn.fi/URN:ISBN:951-40-0705-0. (In Finnish with English summary).

Keltikangas, M., Seppälä, K. 1966. The relative profitableness of seeding and planting on open swamps. (Kylvön ja istutuksen taloudellinen edullisuusjärjestys soilla. Eräitä laskelmia). Suo, 17, 31-38. Available online: http:/ / www. suo.fi/article/9336.

Laine J., Vasander H., Hotanen J.-P., Nousiainen H., Saarinen M., Penttilä T. 2012. Peatland site type guide. (Suotyypit ja turvekankaat - opas kasvupaikkojen tunnistamiseen). Helsinki, Metsäkustannus Oy. 160 pp. (In Finnish).

Lieffers, V.J., MacDonald, S.E. 1990. Growth and foliar nutrient status of black spruce and tamarack in relation to depth of water table in some Alberta peatlands. - Canadian Journal of Forest Research, 20, 805-809. http:/ / dx.doi. org/10.1139/ x90-106.

Lukkala, O.J. 1938. Afforestation of drained peatlands. (Ojitettujen soiden metsittämisestä). - Silva Fennica, 46, 43-57. https://doi. org/10.14214/sf.a13939. (In Finnish).

Luoranen, J., Viiri, H. 2012. Soil preparation reduces pine weevil (Hylobius abietis (L.)) damage on both peatland and mineral soil sites one year after planting. - Silva Fennica, 46(1), 151-161.

Mannerkoski, H. 1975. Hummock-building method in reforestation of an old drainage area. (Vanhan ojitusalueen uudistaminen mätästysmenetelmällä). - - Suo, 26(3-4), 65-68. Available online: http://www.suo. fi/article/9444. (In Finnish with English summary).

Moilanen, M., Issakainen, J. 1981. Effect of fertilization and soil preparation on the regeneration of birch and spruce on thick peat soils in Kainuu. (Lannoituksen ja muokkauksen vaikutus kuusen ja koivun uudistumiseen eräillä Kainuun vaara-alueen paksuturpeisilla soilla). - Folia Forestalia, 481. 16 pp. Available online: http://urn.fi/ URN:ISBN:951-40-0530-9. (In Finnish with English summary).
Moilanen, M., Issakainen, J. 1984. Effect of drainage, fertilization and soil preparation on nautral regeneration of low sedge pine swamp. (Ojituksen, lannoituksen ja muokkauksen vaikutuksesta luontaiseen uudistumiseen piensararämeellä). - Metsäntutkimuslaitoksen tiedonantoja, 133. 17 pp. Available online: http:/ / urn.fi/URN:ISBN:951-40-0975-4. (In Finnish).

Moilanen, M., Ferm, A., Issakainen, J. 1995. Development of Norway spruce and birch seedlings in regeneration on spruce mires. (Kuusen- ja koivuntaimien alkukehitys korven uudistamisaloilla). - Metsätieteen aikakauskirja, 2, 115-130. https://doi. org/10.14214/ma.5950. (In Finnish).

Mueller-Dombois, D. 1964. Effect of depth to water table on height growth of tree seedlings in a greenhouse. - Forest Science, 10(3), 306-316. https://doi.org/10.1093/ forestscience/10.3.306.

Nilson, M.E., Hjältén, J. 2003. Covering pine-seeds immediately after seeding: effects on seedling emergence and on mortality through seedpredation. - Forest Ecology and Management, 176(1-3), 449-457. https://doi.org/10.1016/ S0378-1127(02)00308-0.

Päivänen, J., Hånell, B. 2012. Peatland Ecology and Forestry - a Sound Approach. Helsinki, University of Helsinki, Department of Forest Sciences. 267 pp.

Pearson, M., Saarinen, M., Minkkinen, K., Silvan, N., Laine, J. 2011. Mounding and scalping prior to reforestation of hydrologically sensitive deep-peated sites: factors behind Scots pine regeneration success. - Silva Fennica, 45(4), 647-667. http:/ / dx.doi.org/10.14214/sf.98.

Pearson, M., Saarinen, M., Nummelin, L., Heiskanen, J., Roitto, M., Sarjala, T., Laine, J. 2013. Tolerance of peat-grown Scots pine seedlings to waterlogging and drought: Morphological, physiological, and metabolic responses to stress. - Forest Ecology and Management, 307, 43-53. http://dx.doi. org/10.1016/j.foreco.2013.07.007.

Place, I.C.M. 1955. The influence of seedbed conditions on the regeneration of spruce and balsam fir. - Canada Department of Northern Affairs and Natural Resources, Forestry Branch, Bulletin, 117. 87 pp.

Saarinen, M. 1993. Treatment of mature forests in drainage areas. (Miten käsitellä uudistamiskypsiä ojitusaluemetsiä).

Metsäntutkimuslaitoksen tiedonantoja, 470, 6-12. Available online: http://urn.fi/ URN:ISBN:951-40-1317-4. (In Finnish).

Saarinen, M. 1997. Effect of site factors on restocking of old drainage areas. A literature review. (Kasvupaikkatekijöiden vaikutus vanhojen ojitusalueiden taimettumiseen Kirjallisuuteen perustuva tarkastelu). - Suo, 48(3), 61-70. Available online: http://www. suo.fi/pdf/article9766.pdf. (In Finnish with English summary). 
Saarinen, M. 2002. Effect of vegetation and site preparation on the restocking of Scots pine and birch on dwarf-schrub and Vaccinium vitisidaea type peatlands forests. (Kasvillisuuden ja maanmuokkauksen vaikutus männyn ja koivun taimettumiseen varpu- ja puolukkaturvekankailla). - Suo, 53(2), 41-60. Available online: http://www.suo.fi/pdf/ article9820.pdf. (In Finnish with English summary).

Saarinen, M. 2013. Artificial and natural seeding of Scots pine in old drainageareas - Uniquefeatures of forest regeneration on peatlands. (Männyn kylvö ja luontainen taimettuminen vanhoilla ojitusalueilla - turvemaiden uudistamisen erityispiirteitä). - Dissertationes Forestales, 164. 64 pp. http://dx.doi.org/10.14214/df.164. (In Finnish with English abstract).

Saarinen, M., Hotanen, J.-P. 2000. Covariation between raw humus layer and vegetation on peatlands drained for forestry in western Finland. (Raakahumuksen ja kasvillisuuden yhteisvaihtelu Pohjois-Hämeen vanhoilla ojitusalueilla). - Suo, 51(4), 227-242. Available online: http://www.suo.fi/pdf/article9807. pdf. (In Finnish with English summary).

Saarinen, M., Alenius, V., Laiho, R. 2013. Effect of soil moisture conditions on seed germination and early seedling development in prepared microsites in peatland forest regeneration areas. (Kosteusolosuhteiden vaikutus siementen itämiseen ja taimien varhaiskehitykseen turvemaan metsänuudistusalan muokkauspinnoilla). -
Suo, 64(2-3), 51-75. Available online: http:/ / www.suo.fi/pdf/article9887.pdf. (In Finnish with English summary).

Saarinen, M., Hotanen, J-P., Alenius, V. 2009. Vegetation succession in prepared microsites in drained peatland forest regeneration areas. (Muokkausjälkien kasvillisuuden kehittyminen ojitettujen soiden metsänuudistamisaloilla). - Suo, 60(3-4), 85-109. Available online: http:/ / www.suo.fi/ pdf/article9869.pdf. (In Finnish with English summary).

Sarasto, J., Seppälä, K. 1964. On sowing of pine in moss and lichen vegetation on drained swamps. (Männyn kylvöistä ojitettujen soiden sammal ja jäkäläkasvustoihin). - Suo, 15(3), 54-58. Available online: http://www.suo.fi/ pdf/article9317.pdf. (In Finnish with English summary).

Seppälä. K. 1966. Seeding and planting in peatlands. (Turvemaiden metsänviljelystä). Suo, 17, 52-54. Available online: http://www. suo.fi/article/9339. (In Finnish with English summary).

Silfverberg, K. 1995. Forest regeneration on nutrient-poor peatlands: Effects of fertilization, mounding and sowing. - Silva Fennica, 29(3), 205-215. http:/ / doi.org/10.14214/sf.a9208.

Wood, J.E., Jeglum, J.K. 1984. Black spruce regeneration trials near Nipigon, Ontario: Planting versus seeding, lowlands versus upland, clearcut versus stripcut. - Information Report O-X-361. Sault Ste. Marie, Ontario, Canadian Forestry Service. 19 pp. 